\title{
Towards the Implementation of Monetary Management in Islamic Economic System based on Recent Developments
}

\author{
Mohammad Kabir Hassan \\ University of New Orleans, United States, \\ Corresponding email: mhassan@uno.edu \\ Muhammad Abdul Rehman Shah \\ University of Engineering \& Technology (UET) Taxila, Pakistan \\ Manzoor Ahmad Alazhari \\ HITECH University Taxila, Pakistan \\ Mohammad Selim \\ University of Bahrain, Bahrain
}

Article History

Received: May 20, $2021 \quad$ Revised: July 27, $2021 \quad$ Accepted: July 28, 2021

\begin{abstract}
Monetary management is an essential part of the objectives of Shari'ah under the umbrella of the preservation of wealth (Ma'al). Our primary sources: Qur'an and Sunn'ah, provide divine legislation on the prohibition of Riba to manage bases of monetary transaction. Further, the juristic tools facilitate scholars to propose solutions to meet the emerging issues on diversified aspects of society. Muslim scholars have always adapted and contributed to the Islamic financial system and regulations, theoretically and practically. In recent decades, Islamic banking and finance has seen strong momentum with double digit growth, fulfilling the monetary requirement of depositors on the liability side along with industry on the asset side. We seek to review the theoretical and empirical literature on Islamic monetary mangement. Monetary management in the Islamic economic context is still an area that needs more research. This paper examines how literature has been developed over time up until modern Islamic economic and banking practices. The findings suggest that Islamic monetary management has been gradually developed in recent years and such development is remarkable steps forward in pursuing Islamic monetary policy independently. In addition, Islamic monetary policy is proved to be relatively more effective compared to interest based conventional monetary policy. The implications of such findings have established new milestones for the central banks of all the countries, including the muslim majority countries for pursuing interest free Islamic monetary policy with full confidence. Furthermore, there are four major views on Islamic monetary policy and the central banks of the world should choose one of the best methods and views for the greater effectiveness of monetary policy because conventional monetary policy has been less effective in bringing full employment and price stability in recent years and financial crisis has crippled the interest based conventional economic systems quite badly.
\end{abstract}

Keywords: Islamic economic system, Islamic Monetary Instruments, Islamic Monetary Management, Riba-Free Products, Effectiveness of Islamic Monetary Policy.

JEL Classifications: G15, E52, E42, G21

Type of Paper: Review Paper

@ IJIEF 2021 published by Universitas Muhammadiyah Yogyakarta, Indonesia All rights reserved

DOI:

https://doi.org/10.18196/ijief.v4i2.11777

\section{Web:}

https://journal.umy.ac.id/index.php/ijief/article/view/11777

Citation:

Hassan, M. K., Shah, M. A. R., Alazhar, M. A., \& Selim, M. (2021). Towards the Implementation of Monetary Management in Islamic Economic System based on Recent Developments. International Journal of Islamic Economics and Finance (IJIEF), 4(2), 177-206. DOI: https://doi.org/10.18196/ijief.v4i2.11777 


\section{Introduction}

Islam advocates a holistic way of life to provide welfare to Mankind by establishing harmony on moral and material requirements of people. Interest free Islamic monetary management is the core to promote Islamic monetary policy for achiving full employment and healthy growth rates of equilibrium real GDP. Interest based monetary policy which had been pursued in most of the countries of the world, including in the muslim majority countries had created the problems of under investment spending, unemployment, depressed economic growth rates, perpetual poverty, and periodic financial crisis. In current times, we have plenty of Islamic economic theories, and these theories and principles can easily be implemented for pursuing successful Islamic monetary policy (Selim 2015, 2019, 2020), especially for providing access to the lender of last resort services for the Islamic Banks (Selim \& Hassan, 2020); for easily financing homes with ljarah based diminishing Musharaka (Selim 2020a); for eliminating interest in trade or Riba al Fadl in foreign currency transactions (Selim 2021); for pursuing Sukuk based open market operation as part of Islamic Monetary policy (Selim 2015) instead of Treasury Bills and other interest based financial papers and securities; for pursuing interest free financing of infrastructure projects and redesigning it with Qard Hasan so that it will be acceptable to all Islamic Schools of Fiqh (Selim 2020); for providing Islamic business based Takaful insurance where the policy holders are both owners and risk takers and there are no middlemen who often deprive the share and benefits of the policy holders; here Policy holders are active participants and driving forces of such Islamic Business based Takaful Insurance and receive hundreds of thousands of Dinars (Here Dinar refers to Bahraini Dinar where 1 Bahraini Dinar=US\$2.65) during their old age when they need it the most, (Selim 2015a); for providing Islamic value based Islamic Cooperative model for poverty elimination (Selim \& Farooq, 2020); for permanently eliminating interest costs in trade deficits financing (Selim 2013) but in reality these wonderful Islamic economic theories have not been implemented correctly. This paper is a humble effort to urge nations of the world, especially the members of the Organization of Islamic Cooperation (OIC) countries to truly implement these theories and thus solving all the above problems of poverty, huge interest payments as part of trade deficit financing, unemployment, low income, widespread interest including Riba al Fadl or interest originating in trade, ineffectiveness in monetary policy and so on.

The motivation of this study is to highlight the importance of all the above theories and many other Islamic economic theories and to create an urgency to adopt such Islamic economic theories for achieving full employment, potential real GDP, eliminating poverty, Riba or interest and many other economic and social problems. Despite the development of full fledged and 
Hassan, Shah, Alazhar, \& Selim | Towards the Implementation of Monetary Management in Islamic Economic System based on Recent Developments

effective Islamic monetary policy as mentioned above (Selim 2015, 2019, 2020), the members of the OIC countries have so far paid little importance but many members of the Organization for Economic Cooperation and Development $(\mathrm{OECD})$ countries are now currently pursuing interest free monetary policy in the form of zero central bank interest rate or even negative central bank interest rate. Such interest free monetary policy yields relatively better economic performance (Selim \& Hassan, 2019) and thus more effective in controlling inflation rates and lowering unemployment rates. Unfortunately, as mentioned, the members of the OIC countries and many other poor nations in Asia, Africa and Latin America are still maintaining high interest based conventional monetary policy and thus complicating the problems of low investment spending, high cost of borrowing, high unemployment rates, widespread poverty, homelessness, severe attacks of COVID 19 and many other problems related to chronic low income and vicious cycle of poverty. The objective of this study is to bridge the gap in the literature by portraying to the world central bankers that Islamic Monetary policy can free all the nations from the curse of interest and can bring back full employment income, output and prosperity and thus can solve the problems of mass unemployment, massive poverty and choronic financial crisis. Therefore, the research question of this study can be stated as follows:

Why the Muslim majority countries and poor countries of the world are reluctant or not pursuing interest free monetary policy?

Why some of the developed capitalist countries are pursuing zero or negative interest based monetary policy while others are not doing so? This study attempts to answer the above issues and to create awareness about the effectiveness of Islamic monetary policy which has already been developed in recent years (Selim 2015, 2019, 2020). Now all the nations should come forward and adopt such interest free monetary policy similar to some of the OECD countries who have been successfully pursuing interest free monetary policy and have had great success in maintaining better economic performance by keeping both unemployment and inflation rates low in recent years. (Selim et al., 2019).

The paper not only analyses the most basic concept of Islamic monetary policy but also emphasizes the implementation plan in real world framework. Developing Islamic monetary policy and many other related economic theories are important, but the implementations are much more important, and the benefits of Islamic monetary policy and Islamic economic theories and principles can only be reaped and derived if such theories are fully and correctly implemented. This paper emphasizes how Islamic monetary policy in particular can be implemented successfully for the benefits of the Muslims and for the rest of the Mankind 
Hassan, Shah, Alazhar, \& Selim | Towards the Implementation of Monetary Management in Islamic Economic System based on Recent Developments

Islamic monetary policy promotes socioeconomic justice and unity among people, nations, and environment. This expands into all aspects of economics such as commerce, banking, trade, etc. In recent times, this has been an area of rising attention. Islamic banking and finance (IBF) has drawn the maximum devotion of researchers and practitioners. Chapra (1985) has explored that the elimination of Riba is an essential characteristic of Islamic economic activities; the establishment of an alternative model of Riba-free economy, has posed a great test to Muslim intellectuals. It should be appreciated that the elimination of Riba is not an isolated injunction. Rather, it is a social, economic and moral philosophy presented in Islamic framework and an integral part of unified and coherent values. So, the ultimate objective is not only to eliminate Riba from the prevailing interest-based system, but to rather present an alternative system for establishing moral and material harmony to promote beneficial and optimal resource allocation, capital formation, stability, and growth of economy. Therefore, monetary management is kept and pursued as an integral part and interconnected transmission mechanism for providing basis to Islamic economic system in modern days.

The Islamic financial system especially gained attention of scholars, investors, regulators, policymakers, bankers, and practitioners after the 2007-2008 financial crisis - in which it servived on sound basis (Shah, Rashid \& Zaman, 2017). We see Islamic banking tools expand beyond Muslim majority countries as many nations are endorsing running Islamic financial institutions (IFIs) parallel to their conventional counterparts. In a nutshell, there is potential need to bridge the gap through exploring the monetary perspective of Islamic economy for the sake of macroeconomic objectives (Chapra, 1985; Hardianto, 2004; Kaleem \& Isa, 2006; Sukmana \& Kassim, 2010; Farhani \& Masood, 2013; Ibrahim, 2017; Rafay \& Farid, 2019; Shah \& Rashid, 2019).

In this paper, we explain how Islamic banks play an important role in monetary management through Islamic financing channel to achieve the economic growth and stability of markets. The main purpose of this study is to guide policymakers for adopting the Islamic monetary policy and banking practices as an alternative to existing interest based conventional system for achieving the objectives of monetary policy of full employment, price stability, high economic growth rates and prosperity.

The paper is divided into seven sections. After introduction in Section 1, Section 2 reviews the literature on monetary management in early Islamic history. Islamic monetary policy in modern context is explained in Section 3. Section 4 covers the prominent views of Islamic monetary policy. Section 5 highlights the increasing share of Islamic finance over the globe as a paradigm shift to monetary management. In Section 6, we note empirical evidences on 
Hassan, Shah, Alazhar, \& Selim | Towards the Implementation of Monetary Management in Islamic Economic System based on Recent Developments

the role of Islamic financial institutions (IFIs) in monetary policy. We conclude the paper in Section 7.

\section{Monetary Management in Early Islamic History}

In early time of Islamic history, the same money which was prevailing was adopted for all purposes. Famous Muslim Historian Al-Baladhuri (البلاذري, 1820-1892) had documented in his book "النقود":

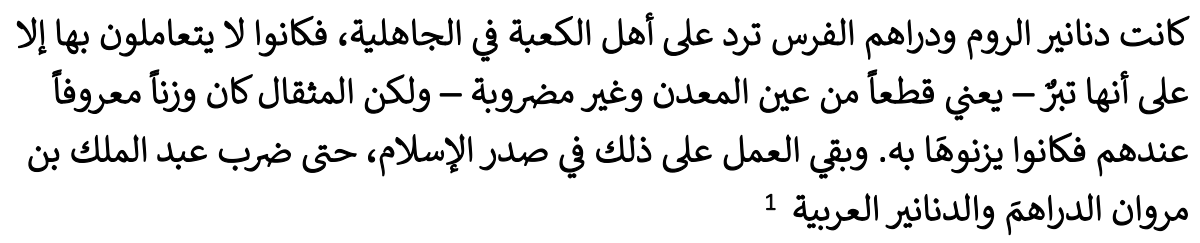

Roman Dinar and Persian Dirham were prevailing before the Prophet Muhammad (PBUH) and were continued in early Islamic period. These were not minted properly, therefore, used to weigh against defined measure of "Misqal-المثقال". This practice continued till Abdul Malik bin Marwan minted Arabic Dinar and Dirham.

Further, Zaitoon (2001) has documented about shape and gold weight in Islamic Dinar as follows:

وجاء شكل الدينار الذهبي الإسلامي الذي سكه عبد الملك عام 77هـ على النحو التالي : نقش على حد الوجهين (الله أحد الله الصمد لم يلد ولم يولد) ونقش على مدار الوجه نفسه (بسم الله ضرب هذا الدينار في سنة سبع وسبعين) أما على الوجه الآخر فقد نقش (لا إله إلا الله وحده لا شريك له) ونقش على مداره (محمد رسول الله أرسله بالهدى ونور الحق ليظهره على الدين كله) أما وزن هذا الدينار فقد كان 4.25 غرام وهو الوزن الشرعي للدينار وكانت نسبة الذهب فيه نحو 96\% لقدكان وقع سك الدينار على بيزنطة بالغ القسوة؛ حيث فقد جستيان الإمبراطور البيزنطي صوابه وأعلن الحرب على عبد الملك؛ ولكنها انتهت بهزيمة القوات

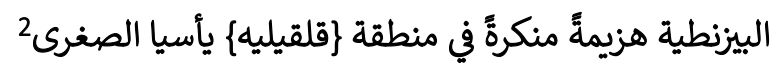

Abdul Malik minted gold based Islamic Dinar in 77 Hijrah of Islamic calander. There was specific written text on both sides of Islamic Dinar pertaing Qur'anic words and a statement with issuing year of 77 Hijrah on one side and the other

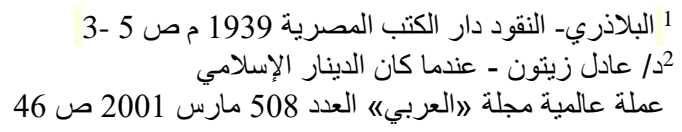


Hassan, Shah, Alazhar, \& Selim | Towards the Implementation of Monetary Management in Islamic Economic System based on Recent Developments

one was reflecting oneness of Allah Almighty and the objective of the Prophet Muhammd (PBUH). The weight of Islamic Dinar was 4.25 GM with $96 \%$ gold as standard of Shari'ah matters. An initiative of Islamic Dinar appeared to replace Byzantium currencies completely and angered Justin, the Byzantine Emperor, who declared war agaist Abdul Malik. However, it ended in a reprehensible defeat by the Byzantine forces in the region of Qalqilya.

Furthermore, Kanon (1974) explored how Islamic Dinar was spread as the primary currency of Muslim states.

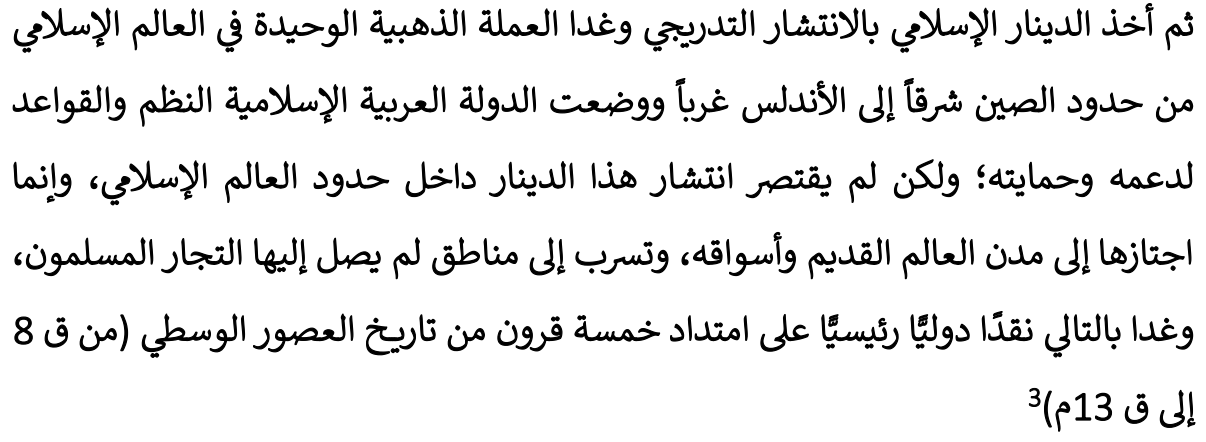

Islamic Dinar appeared as a powerful currency from China in the East to Andalus in the West. The Islamic Arab state established rules and regulations to support and protect it, but the spread of Islamic Dinar was not limited within the borders of the Islamic world. Rather, it passed it to the cities and markets of the ancient world, and it leaked to areas where Muslim merchants did not reach. Consequently, it became a major international currency throughout the five centuries of medieval history (from 8th to 13th century).

Chapra (1996) has reported inadequate amount of notable evidence of monetary policy in the early Islamic history during the time of the Prophet Muhammad (PBUH). During this era, the monetary system consisted of bimetallic standards of gold (Dinar) and silver (Dirham) coins. These coins were ciculating at a ratio of 1:10, respectively. This ratio remained stable until 661 A.D (40 A.H in Islamic Calendar). Over the passage of time, these two metals had been fluctuating in terms of their relative prices. The exchange rate between Dinar and Dirham reached 1:12 in the Umayyad period (41AH/662AD-132AH/750AD), while the exchange rate reached 1:15 in the Abbasid period (132AH/750AD-656AH/1258AD). The ratio eventually fluctuated tremendously over time in various parts of world. This brief evolution of money is reflected in figure 1.

عبد الله كنون- الدرهم والدينار عملتان عايثتا العرب بضعة عشر قرناً مجلة 》العربي《 العدد 187 يونيو 1974 م $36^{3}$ 
Hassan, Shah, Alazhar, \& Selim | Towards the Implementation of Monetary Management in Islamic Economic System based on Recent Developments

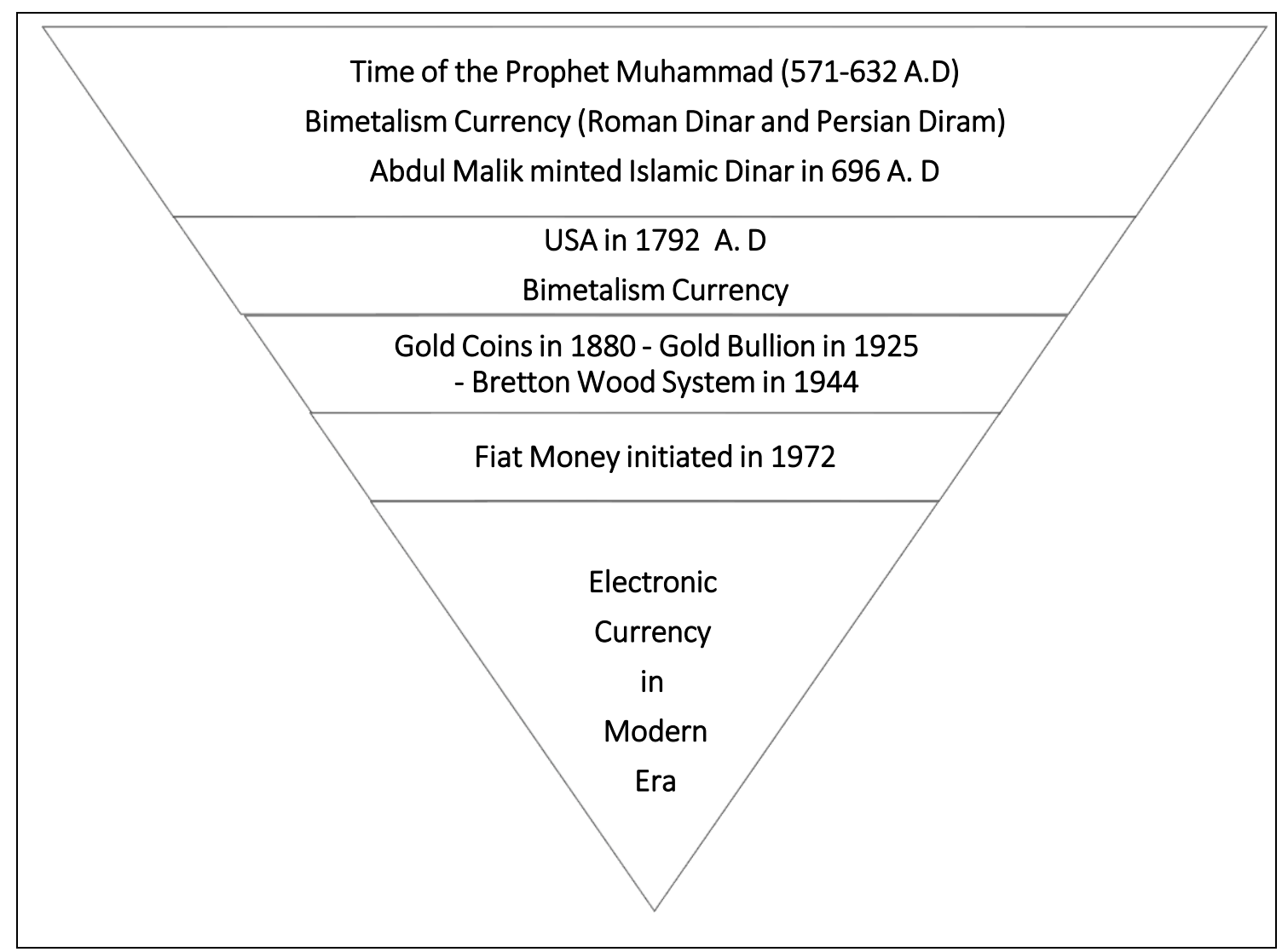

Figure 1. Historical Evolution of Currency

Source: Chapra (1996) with Authors' modification

In the early Islamic state of Madina, there was no concept of shifting the money supply through discretionary measures due to a lack of a banking system to enforce monetary policy. Moreover, there was a working commodity system which has been used widely and extensively. Similarly, credit was almost absent as only a few traders used it. In this simple market, Riba was nullified from business transactions in five distinct divine revelations from Allah, the glory be to Him, the Exalted. This governed the transaction of commodity money system (Barter System) and this regulation, the " ربالبيوع Riba al Fadal", incorporated in six commodities. The Prophet Muhammad (PBUH) said:

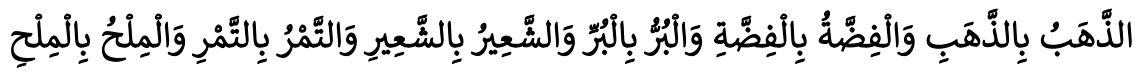

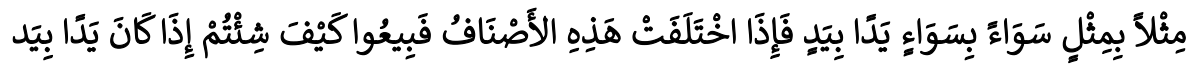

"(Don't sell) Gold for gold, silver for silver, wheat for wheat, barley for barley, dates for dates and salt for salt - like for like, equal for equal, and hand to hand; if the commodities differ, then you may sell as you wish, provided that the exchange is hand to hand." (Muslim Hadith \#1587) 
Hassan, Shah, Alazhar, \& Selim | Towards the Implementation of Monetary Management in Islamic Economic System based on Recent Developments

The fist two commodities, Gold and Silver (Dinar and Dirham), were the prevailing currencies. The remaining four were the staple consumable commodities of consumer basket during this era. We see evidence about monetary management as prices soared in the markets of Madinah. Then, people came to the Prophet Muhammad (PBUH) and requested to fix the price. The Prophet rejected this on the notion of not interfering in the normal demand and supply forces of the market. Accordingly, the Prophet Muhammad (PBUH) said:

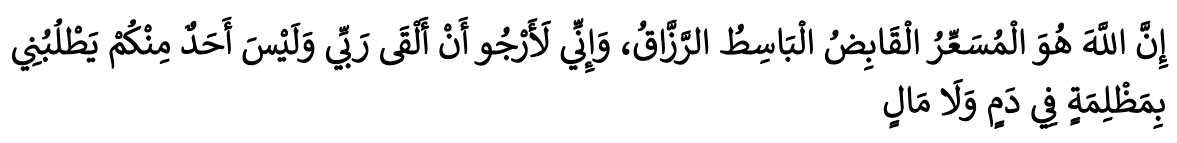

Allah, the glory be to Him, the Exalted, is the real price maker, controls plenty or shortage of anything and $\mathrm{He}$ is the sole provider. I wish to see to Him without injustice to any one of you in your blood or in your money" (Abu Dawud, 3451).

As-Sadr (1989) noted that products like that of "promissory notes" and "negotiable instruments" were found during this time period as well. These were regulated in the way that their credit was not playing any role in the creation of money. In other words, promissory notes or bills of exchange were used to buy real commodities or to receive the specific quantity of money with zero fee. Technically, these documents could never be issued merely for the purposes of credit in the market. A creditor could sell these documents, but a debtor was not allowed to sell them further without taking the possession of underlying assets or commodities to comply with basic requirements of Islamic business law. There was no market to sell or buy the negotiable instruments in a speculative way. Thus, credit could not create money through debt instruments. This arrangement appeard to affect the equilibrium of the commodity and the money markets based upon transaction where money is achieved only through rendering an economic service in the labour market or through selling a commodity in the goods market. In other words, money was exchanged in business activity that was based on real value-addition and in compliance with Shari'ah. As a result, the equilibrium of money and goods markets were determined in the economy in such a way hat the volume of money was always equal to the value of the produced goods. Further, Islahi (2008) has classified Islamic economic thoughts in six phases till the modern inception of Islamic banking and finance and explored that modern monetary policy instruments, open market operation, policy rate announcement, forex management, and the trading of the negotiable instruments were not a part of monetary management in the early Islamic period. 
Hassan, Shah, Alazhar, \& Selim | Towards the Implementation of Monetary Management in Islamic Economic System based on Recent Developments

\section{Interpretation of Islamic Monetary Policy in Modern Era}

The development of money management has raised concern for important issues about money, banking practices, and monetary policy operations in the $20^{\text {th }}$ century (Iqbal, 1997; Siddiqui, 2006; Abdul-Rahman, 2011). An initiative of modern banking practices, globalization of financial intermediation, establishment of financial institutions in Muslim states, excessive use of paper currency and then electronic transactions, trade of stocks across the borders, and the increase in public debt have raised questions for jurists, Islamic bankers, regulators and Islamic economist. To meet these queries, Muslim economists and Modern jurists tried to revisit Western institutions with an objective to make them Riba-free with necessary modification or to devise Shari'ah-compliant alternatives that may achieve the objectives of public policy as well. These theories are institutionalized due to the rising political independence during this time, that allowed Islamic business and monetary practices to be tested. Similarly, their desire to spell out the distinctive Islamic economic approach, especially separating them from capitalism and socialism, led them to bring several fresh formulations in the domain of monetary policy.

Ahmad (1984) noted that a significant contribution in the field of monetary policy was made at the $1^{\text {st }}$ International Islamic Economics Conference which was organized at Makkah, Kingdom of Saudi Arabia in February 1976 and the New International Economic Order that was held in London, United Kingdom in 1977. In line with same agenda, a seminar on Islamic Monetary and Fiscal Economics held at Makkah in 1978 and the selected papers were edited by Ariff (1978). As an independent book, these policy papers were published by International Centre for Research in Islamic Economics (ICRIE), King Abdulaziz University (KAU) Jeddah. Likewise, a seminar was organized on same agenda in 1981 in Islamabad, Pakistan. Another international conference on Islamic Banking and Strategies for Economic Cooperation was held in Baden-Baden, Germany in 1982. In continuing, the $2^{\text {nd }}$ International Conference on Islamic Economics was held at Islamabad, Pakistan in 1983. A sizable number of books, monographs, research papers and proposals were produced containing innovative ideas and fruitful discussions as proceedings of these conferences and seminars. It must be noted that the Council of Islamic Ideology of Pakistan contributed the most significant intellectual-cumoperational blueprint to eliminate the Riba (Interest) from a modern interestbased economy through Panel of Islamic Scholars, Economists and Bankers in 1980. Similarly, Chapra (1985) has explored that this report of Council of Islamic Ideology, Pakistan proved a milestone towards the development of an interest-free model of modern practices of Islamic economy. This report was derived from intellectual work of contemporary Muslim scholars in the past decade towards an interest-free economy. 
Hassan, Shah, Alazhar, \& Selim | Towards the Implementation of Monetary Management in Islamic Economic System based on Recent Developments

Furthermore, Chapra (1985) has established the three main objectives of Islamic monetary policy: i) to achieve the economic well-being of human beings with full employment and optimum rate of economic growth for the economy; ii) to ensure stable value of money and iii) to maintain socioeconomic justice and fair distribution of income and wealth among masses. The former two objectives are considered in conventional monetary theory, and the third one has been added as a new dimension contributed through Islamic monetary literature. Moreover, Ariff (1988) and Uzair (1982) have raised some introductory questions on the applicapability of conventional monetary policy in the 1978 seminar in Jeddah, Saudi Arabia. The literature on Islamic money has started flourishing after this in line with the objectives of Shari'ah.

\section{Prominent Views on Islamic Monetary Policy}

Several Islamic economists have presented views, but four views were dominant on this aspect of Islamic monetary policy. First, Al-Jarhi (1983), a pioneer contributer of monetary policy to develop an interest-free financial structure, views primary monetary policy players to be: the central bank, commercial banks, private sector business, and the treasury. It is interesting that he has come with an idea of debt instruments with zero-interest. There will be neither the required reserve ratio nor the discount rate would exist as policy instrument in interest-free monetary policy. In the final verdict, he supports the monetarists rule to manage the money supply in Islamic economic framework. Second, Chapra (1985) and his followers adopted the existing conventional tools of monetary policy with necessary amendments. This strategy would help establish an ideal position of monetary policy step by step. Third, some others have proposed to use equity-based profit-loss sharing (PLS) securities for monetary management along with other Shari'ah compliant instruments in line with second view. Although Naqvi (1981) has criticized an equity-based economic system because this system makes the return on investment unstable as compared to conventional interest-based system. Moreover, investors' expectations are uncertain in returns on investment. Therefore, there is need to hedge the risk of loss through deposit insurance scheme for depositors, otherwise the financial market in particular and the whole economy in general will become highly unstable. Likewise, Naqvi (1981) and Kuran (1986) are convinced that people of this Islamic monetary society will not save and invest due to not having interest as a motivating tool. As a result, the state must intervene to compel them to participate in investment activities for expansionary monetary policy. Further, Kuran (1986) thinks that all the banks will not agree to finance the firms on PLS principle of Islamic finance. 
Hassan, Shah, Alazhar, \& Selim | Towards the Implementation of Monetary Management in Islamic Economic System based on Recent Developments

Zarqa (1983) argues that every real business must face uncertainties, and therefore, contrary to what Naqvi (1981) states that equity financing increases these uncertainties. Rather, it reorganizes the consequences of uncertainty to all business partners promoting stability to a business entity. Each head of business partner will bear specific portion of loss without affecting inversely normal business activities to meet commitments. In contrast, the conventional system relieves the financier from bearing any type of risk in terms of uncertainties by transferring the complete risk profile to investor. So, interest-based system leads to instabilities and economic disturbances in market. Similarly, Khan (1986) argues that Islamic financial system adjusts faster to different shocks as compared to the existing traditional system. Further, he mentions, with reference to Henry Simons, that conventional banking system is unstable leading to financial crisis because of interest-based mechanism and proposed an equity-based financial system with $100 \%$ reserve banking in line with equity-based Islamic economic system. Khan (1986) also notes that several Islamic economists have developed different frameworks of monetary policy in IS-LM framework. In these frameworks, an interaction of monetary policy and the real sector of the economy must go hand in hand and be a top priority.

Khan and Mirakhor (1990) developed a theoretical model through IS-LM model of Islamic economic system. They have explored how monetary policy actions would affect macroeconomic factors. In this model, a variation in money supply and Mudaraba-based financing would affect the macroeconomic variables equally. As a result, an expansionary monetary policy will decrease the rates of return and increase an aggregate output. Likewise, Khan (1986) favoured to regulate PLS ratios to meet the objective of monetary management. He has explained that these monetary actions affect only the new deposits of Islamic banks and not existing deposits. He has discussed the two-window banking model. The first window is specific for demand deposit where $100 \%$ reserve would be maintained with no return to be given back. The other window would be utilized for PLS investment purposes or equity investment where there would not be any guarantee on principal amount and reserve would also not be required. Khan (1986) built his modelling framework in line with the model of Meltzer (1951). Khan (1986, 1992) has presented a macroeconomic model in which monetary policy would work like interest-based economy with the exception that Islamic monetary model will have a better speed of adjustment monetary disequilibrium. In contrast, Hasan (1991) has criticised some aspects of Khan and Mirakhor's model. He has admitted that the rate of return ( $r$ ) received by the banks on loans (lending rate) must be related to the rate the banks (rb) liable to their liabilities in accordance with Khan and Mirakhor (1990). In fact, $r$ and $r b$ cannot be zero even if we simplify the analysis by assuming that operational 
Hassan, Shah, Alazhar, \& Selim | Towards the Implementation of Monetary Management in Islamic Economic System based on Recent Developments

and other costs of bank are zero. If someone proves that $r b$ is less than $r$, the results of the models would be challenged as the equality of these two rates is the foundation of all analysis. Siddiqui (2006) has also supported Hasan (1991) that the equality of the two rates is not possible based on two-tier Mudaraba model.

Once again, Khan and Mirakhor (1994) have highlighted the role of Mudaraba mode for deposit mobilization, and the role of lease financing instruments available in the Islamic financial market. They provided a set of information like conventional existing market with necessary modifications. Further, they have pointed out that along with the Islamic banking system, the primary, secondary and money markets are required to meet the basic requirement of monetary policy actions in Islamic economic framework. Indeed, Mudaraba and Musharaka certificates would appear as necessary tools of monetary policy in line with Shari'ah legitimacy. They have also framed macroeconomic stability in terms of price stability and efficient balance of payments as the prime objectives of these policy actions.

Khan (1996) has also contributed theoretically with a model which determines national income, snapshots of economic growth in Islamic economic framework. He has emphasized that growth can be manipulated through mobilization of human resources on the supply-side in Islamic financial system. The said system produces an implicit Islamic macroeconomic system, resulting to full employment, economic growth and further development. Similarly, Choudhry and Mirakhor (1997) have concentrated on the instruments of Islamic monetary policy. They have discussed about how to use equity-based securities of government with specific rates of returns based on budgetary surplus for the monetary management in Islamic economic framework. There is a tremendous contribution titled "IIIE's Blueprint of Islamic Financial System (1999)" presented by International Institute of Islamic Economics (IIIE) from International Islamic University (IIU), Islamabad, Pakistan on the issue of monetary management of an Islamic economy. It is, however, not explored largely in the literature of Islamic economics and finance. It outlines institutional framework, role of central bank, policy instruments and possible choices for monetary management in an Islamic economy.

Tahir (2013) gave two messages in his theoretical study on institutional framework with specific reference to fiscal and monetary policies in an Islamic economy: (1) a fresh thinking is invited for the revival at the systemic level. There are possible changes that would help in achieving the objectives of policy and (2) a place to work out through an active role of government on both economic and distributive aspects of a public policy. In his opinion, the government should confine itself to the governance only. In the light of 
Hassan, Shah, Alazhar, \& Selim | Towards the Implementation of Monetary Management in Islamic Economic System based on Recent Developments

Shari'ah, the development of monetary aspect would be helpful in achieving the economic goals of a country. Even on the monetary side of an economy, the prime role of the central authority may be largely regulatory.

The fourth view is proposed by Selim (2019) where Qard Hasan based monetary policy has been designed in the light of the verses of the Holy Qur'an and and the Hadith of Prophet Muhammad (PBUH) and it has been proved that such monetary policy is most effective in bringing full employment and controlling inflation. In this Qard Hasan based monetary policy, Selim (2019) also proposed the change in the direction of money supply and monetary transmission mechanism from the "Central bank to commercial banks" to "Central bank to the final users such as the poor and destutes and all those who deserve of additional increase in money supply or for whom money supply will be intended to" in the light of the verse 7 of Sura Hasr:

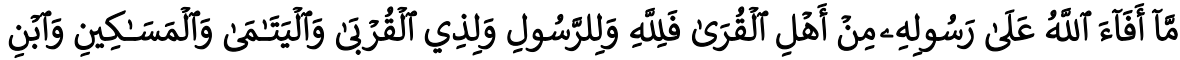

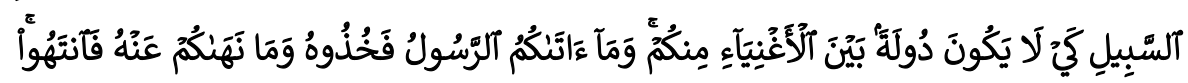

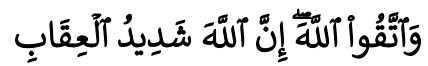

"What Allah has bestowed on His Messenger from the people of the townships, - belongs to Allah, - to His Messenger and kindred and orphans, the needy and the wayfarer; in order that it may not (merely) make a circuit between the wealthy among you. So, take what the Messenger assigns to you, and deny yourselves that which he withholds from you. And fear Allah; for Allah is strict in punishment" (Qur'ān, 59:7).

Allah, the glory be to Him, the Exalted, enjoins among others, that the wealth will not be a perpetual distribution among the rich from among you. The owners of the commercial banks are the wealthy cohort of population and such wealthy population reap most of the benefits of the expansionary monetary policy while the poor cohort of population may not even qualify for the loans because of the lack of collaterals in the form of assets, jobs, and accumulated wealth. Reversing this perpetual flow of wealth from the rich to the poor will permanently create vibrant economic activities in the economy where the poor cohort of population will not be ignored rather will be embedded as actors and key players in new economic activities. Such inclusiveness of the poor cohort of population in Islamic monetary policy has also great significance during the recession when the central bank increases money supply, but the commercial banks stop lending because of the fear of the loan losses but if the money supply directly flows to "whom it will be intended to" then the ineffectiveness of monetaray policy can easily be avoided, and the economy can be brought to automatic full employment 
Hassan, Shah, Alazhar, \& Selim | Towards the Implementation of Monetary Management in Islamic Economic System based on Recent Developments

instanteously. Selim (2020) also proposed Istisna'a based monetary policy where he showed that if Istisna'a is backed by Qard Hasan for the Producers, Builders and Manufacturers then such monetary policy will not only be most effective, but Istisna'a-Qard Hasan mode of financing will also be accepted by all the Schools of Figh, and production cost will be the lowest while the quality of the product(s) will be the highest. Selim (2015) also propounded Sukuk based monetary policy as an alternative to fixed interest-based Treasury Bills (T-Bills) and other interest-based securities which are often sold and bought in open market operations as part of the monetary policy. Sukuk can be lucrative and may offer relatively higher rates of halal return compared to Tbills, and Islamic banks can buy and sell sukuk and thus can minimize the requirements of holding huge amounts of idle cash for the fear of default risk. Fear of the default risk for the Islamic banks place highest possible constraints on the path of growth strategy of Islamic banks and both Sukuk based monetary policy and Qard Hasan based monetary policy can eliminate such risks and fear for the Islamic banks because in Qard Hasan based monetary policy, Islamic banks can take full advantage of the the service of the lender of last resort (LOLR) of the central banks and Islamic banks can borrow from the Central bank on the basis of Qard Hasan at zero interest rates. Currently, many members of the OECD countries are pursuing interest free or even negative interest based monetary policy which proved to be relatively more effective (Selim et al. 2019) and such interest free or negative interest based monetary policy partly resemble Qard Hasan based monetary policy. However, Qard Hasan is much more comprehensive, more humane, and full of blessings, bounties, and fosters social harmony, cohesion, and prosperity.

\section{Increasing Share of Islamic Finance around the Globe: Need to Revise Monetay Management}

The global Islamic banking and financial industry has achieved a rapid growth in different markets, and it expanded into new geographies. Therefore, central banks of concerning countries should keep an eye upon responses of Islamic banking industry in conducting monetary policy to achieve macroeconomic goals. Moreover, as compared to conventional banks, the distinguishing nature of Islamic banks affects the composition of assets and liabilities of them. Otherwise, it would appear as problematic segment of economy to transmit effective monetary policy for macroeconomic targets. There would appear monetary policy puzzles, making it ineffective.

In last quarter of $20^{\text {th }}$ century, theoretical literature of Islamic economics and finance moved to establish IFIs in Islamic countries (Islahi, 2008). These institutions became a central hub inviting to meet financial obligations, and to 
Hassan, Shah, Alazhar, \& Selim | Towards the Implementation of Monetary Management in Islamic Economic System based on Recent Developments

design structure of products in compliance with Islamic law of financial contracts. Parallel to these innovative steps, Iqbal (1997), Naqvi (1981), AlJarhi (1983), Ahmad (1984), Chapra (1985, 1996), Kuran (1986), Ariff (1988), and Selim (2015, 2019, 2020) provided basis to Islamic monetary management in modern context. Currently, Islamic banking industry is an emerging market with a growing share over the globe, especially, with concentration in Islamic regions. The global Islamic financial industry still managed to contribute with growth in 2018, although it grew slowly as compared to 2017 . The industry assets grew with $6.9 \%$ across banking, capital markets and takāful with an amount of \$2.05 trillion, which was expected to reach $\$ 2.19$ trillion (For details, see Table 1 ).

Table 1. Global Islamic Financial Industry by Sector and Region (USD billion)

\begin{tabular}{lcccccc}
\hline \multicolumn{1}{c}{ Region } & $\begin{array}{c}\text { Banking } \\
\text { Assets }\end{array}$ & $\begin{array}{c}\text { Sukuk } \\
\text { Outstanding }\end{array}$ & $\begin{array}{c}\text { Islamic } \\
\text { Funds } \\
\text { Assets }\end{array}$ & $\begin{array}{c}\text { Takaful } \\
\text { Contributions }\end{array}$ & Total & $\begin{array}{c}\text { Share } \\
\%\end{array}$ \\
\hline Asia & 266.1 & 323.2 & 24.2 & 4.1 & 617.6 & 28.2 \\
GCC & 704.8 & 187.9 & 22.7 & 11.7 & 927.1 & 42.3 \\
MENA (ex-GCC) & 540.2 & 0.3 & 0.1 & 10.3 & 550.9 & 25.1 \\
Africa (ex- & 13.2 & 2.5 & 1.5 & 0.01 & 17.2 & 0.8 \\
North) & 47.1 & 16.5 & 13.1 & ---- & 76.7 & 3.5 \\
Others & 1531.3 & 530.4 & 61.5 & 27.7 & 2190 & 100.00 \\
\hline Total & &
\end{tabular}

Source: Islamic Financial Services Industry Stability Report, IFSB, 2019.

The growth of IFIs lies in exploration of Islamic monetary theory and practice for deepening its impact in accordance with the objectives of Shari'ah. It is the need of the time for other Muslim countries, such as Sudan and Iran that claim to operate fully Shari'ah-compliant banking systems, to take accurate steps to develop Islamic financial industry. In this regard, Malaysia, Brunei, Indonesia, Bahrain, Pakistan and UAE have worked on the regulations of Islamic monetary system and launched some Islamic monetary instruments as a first step to direct money and capital market in this direction. Indeed, Sukuk are the dominant base to these monetary instruments. However, we need to harmonise the differences on structure of Sukuk to achieve the global acceptance of these instruments for liquidity management and portfolio diversification of IFIs. Mansoori (2010) has noted that combined contacts of Sukuk instruments are debatable among Islamic jurists because such instruments are not devised properly. Some grey and black areas of these Sukuk are yet to be refined from Shari'ah perspective. Chaudary and Mirakhor (1997) have suggested that most of central banks use moral suasion as a supplement to other instruments. It is difficult to assess its merits and demerits since it may take many forms from persuasion to directives. This 
Hassan, Shah, Alazhar, \& Selim | Towards the Implementation of Monetary Management in Islamic Economic System based on Recent Developments

instrument should be used only in rare situations in order to give incentive for other instruments to become effective.

In Ernst \& Young's latest Islamic Banking Competitiveness Report (2017), Islamic financial market has expanded rapidly over the past decade reflecting the demand for Shari'ah-compliant services and products over the globe. Over 2000 to 2016, Islamic banks' capital has grown from \$200 Billion to an incredible $\$ 3$ Trillion and expected to touch $\$ 4$ Trillion by the early 2020s. The annual growth rate of $19.7 \%$ in Islamic financial sector is putting pressure on conventional financial institutions to offer Shari'ah-compliant services in the market, especifically, the adoption of Islamic products by users from nonMuslim majority countries is also showing no signs of slowing down in Islamic banking market.

It is witnessed that the contribution from the other regions, Europe and SubSaharan Africa especially, has been very low. But the future growth prospects are very brilliant because of current strategies and projects in several new and niche Islamic financial markets to move forward in term of infrastructure development. Based on historical growth, Islamic financial sector is deepening its impact in top markets addressing the requirements of customers on religious basis. We find these Islamic financial developments mainly in the Gulf Cooperation Council (GCC), the Middle East and North Africa (MENA) region, and selected countries of Asia (Ernst \& Young's latest Islamic Banking Competitiveness Report 2016). In sum, Islamic financial industry is growing across banking, capital markets, and takāful with continuous rising trends over the globe. The growth of Islamic financial market also attracts researchers and practitioners to explore monetary management in Islamic context.

\section{Empirical Evidence on the Role of IFIs in Monetary Policy}

In more recent empirical literature on monetary policy, the instruments and the transmission mechanism in Islamic economic framework are parallel to existing conventional interest-based system. Monetary policy transmission is the mechanism through which monetary policy transmits the decisions into changes in the real GDP, the rate of inflation, and other macroeconomic indicators (Taylor, 1995). Similarly, Ireland (2005) defined that transmission mechanism of monetary policy explains how changes in the nominal money stock or policy rate affect the macroeconomic variables; aggregate output and level of employment. In economic theory, monetary policy transmission mechanism is commonly termed as "black box" (Bernanke \& Blinder, 1995). These economic objectives can also be achieved through providing accurate Shari'ah based channels which will only satisfy Muslim community, rather 
Hassan, Shah, Alazhar, \& Selim | Towards the Implementation of Monetary Management in Islamic Economic System based on Recent Developments

fulfill the requirement of market. Notably, the financial environment, structure of economy, global financial interaction determines the suitability of a transmission channel in any economy (Bernanke \& Blinder, 1995; Obstfeld \& Rogoff, 1996). Mishkin and Schmidt-Hebbel (2007) have explored the importance of an effective transmission channels of monetary policy to lubricate the flow of resources from all segments of the economy to different part of a country for holistic development. Furthermore, they have explored that the priority of any monetary policy authority should be price stability and economic growth, while the preferences of any monetary policy depends on political factors, on economic environment and on the quality of economic institutions.

For understanding macroeconomic fluctuations, the role of credit has been a source of curiosity among researchers over time. The banks' credit channel indicates the role of the banking sector in transmission of the effects of monetary policy actions to the real economy. In dual-banking (Islamic and conventional banks) economies, policymakers must consider the increasing role of Islamic banks parallel to their conventional counterpart in provision of credit to economy. The banks' credit responds in a specific manner when a monetary policy action is exercised on the economy. Banks' credit is found important in the transmission mechanism of monetary policy in any modernday economy.

Akteruddin (2016) has noted that Islamic finance has developed in the last four decades but a remarkable contribution in domain of Islamic monetary management is found in the eighties and nineties of $20^{\text {th }}$ century. Kia and Darrat (2007) discussed PLS banking systems through modelling money demand behaviour in Islamic Republic of Iran for the prtiod of 1966-2001. The demand equation for PLS deposits is found to be significant after different policy and non-policy shocks. They have concluded that PLS instruments are reliable for monetary management in line with theoretical evidence of Chapra $(1992,1996)$ and Khan (1986) who indicated about stable trends through development of PLS system in Islamic economic system.

Zulkhibri, M., and Sukmana, R. (2017) investigated the responsiveness in the financing rate structures of Islamic banks when central bank changes monetary policy for the Indonesian economy by using panel data for the periods of 2003 to 2014 and found that 'the financing rate has a negative impact on financing at Islamic banks.'

Zulkhibri, M., Manap, T. A. A., and Muneeza, A. (2019) have clearly differentiated and outlined the functions of conventional monetary policy and Islamic monetary policy and emphasized that contemporary Islamic monetary 
Hassan, Shah, Alazhar, \& Selim | Towards the Implementation of Monetary Management in Islamic Economic System based on Recent Developments

policy tends to be 'heavily influenced' by conventional economic thoughts and such trend must be reversed.

In addition, Zulkhibri, M., Ismail, A. G., and Hidayat, S. E. Eds. (2016) emphasized the interactions and linkages between macroprudential policy and financial stability and urged that central bank must adopt Macroprudential policies and approaches for achieving financial stability and averting recurring financial crisis.

Furthermore. Zulkhibri, M. (2018) found no significant difference between financing as well as lending by Islamic banks and conventional banks in response to the changes in monetary policy by the central bank. The author also suggests focusing more on profit and loss sharing instruments compared to debt-based financing and lending.

Alaro and Hakeem (2011) explain the basic differences of contractual obligations between Islamic versus conventional banks that seem to have differential impacts on credit supply in dual-banking system. They explore that Islamic banks do not deal in interest-based loans and participate on a PLS basis in industry. Moreover, the rate of return on equity shares is not determined through speculation; rather they accept the effects of real economy. Sanrego and Rusydiana (2013) explain how inflation is controlled in Islamic banks through replacing the loan-based credit by PLS modes of Islamic financial contracts. This market interaction leads to a balance between nominal and real segments of the economy. Similarly, Majid and Hasin (2012) explore the differences on balance sheets of both types (Islamic and conventional) banks along with fulfilling the same type of demand of market for consumer and corporate financing. Depository accounts are devised on basis of Qard and Mudarba, whereas the financing is based on Murabaha, Mudarba, Musharakah, diminishing Musharka, ljarah, Salam and Istisnaa contracts. Likewise, Adebayo and Hassan (2013) and Mansoori (2010) have added that these Shari'ah-compliant contracts incorporate built-in business ethics which can be found in pratices. Further, the capital structure is also explored with unique characteristics of Islamic banks in case of Pakistan (Shah, Rashid, \& Zaman, 2017). Furthermore, the differences led a policymaker to keep an eye on the distinguishing features of Islamic banks in dual banking economies; otherwise, there may appear unwanted results of monetary policy (Chapra, 1985; Chaudary \& Mirakhor, 1997; Kaleem \& Isa, 2006; Sukmana \& Kassim, 2010; Farhani \& Masood, 2013; Ibrahim, 2017; Rafay \& Farid, 2019; Shah \& Rashid, 2019).

Charap and Cevik (2011) analyse the impact of the interest rate on depository accounts of conventional banks and the impact of the rate of returns on PLS- 
Hassan, Shah, Alazhar, \& Selim | Towards the Implementation of Monetary Management in Islamic Economic System based on Recent Developments

based depository accounts of Islamic banks in case of Malaysia and Turkey. They found that there is sound cointegration and correlation and noted that conventional banks' interest rates Granger cause the returns of then Islamic banks in depository accounts using the pairwise causality tests and the multivariate causality tests. Furthermore, Islamic banks fund their operations through participatory PLS arrangements at liability side, but they tend to use non-participatory modes of Islamic finance in creating their assets. In addition, Islamic banks are competitive with conventional counterpart through availing profit equalization reserves (PER). They conclude that the instruments of Islamic financing require an efficient Islamic financial market to run the operation properly. Similarly, regulatory and supervisory framework is also necessary to organize a well functioning market. This arrangement is prerequisite to observe an efficient monetary policy through Islamic financial market.

In recent years, many economists have investigated comparative differences of monetary transmission mechanism between Islamic and conventional banks in countries having dual monetary system. Sukmana and Kassim (2010) have investigated the role of Islamic banks in monetary policy for Malaysian economy. For empirical evidence, this transmission mechanism of monetary policy is examined through the co-integration test, the impulse response functions, and the variance decomposition analysis. They have found that Islamic banks' financing and deposits are the important determinants to the monetary transmission process in the Malaysian economy. Islamic deposits and financing are found significant variables in response to monetary policy actions to achieve the real output. They have recommended that monetary authorities should consider the Islamic banking industry while designing policy instruments for dual banking economy. They suggest developing the Islamic money market to achieve a well-functioning market and to accelerate the transmission mechanism of monetary policy through Islamic banks.

Cevik and Teksoz (2012) investigated the monetary policy transmission for GCC and evaluated the effectiveness of monetary policy practices in economy of concerned countries. For empirical investigation, they used SVAR model with quarterly data over the period of 1990-2010. Their results confirmed the significance of the interest rate and banks' lending channel. Because of the pegged exchange rate regimes, the exchange rate channel of monetary policy is found insignificant. It is notable that the important determinants of the interest rate and bank lending channels work through the bank balance sheets in transmission process of monetary policy. They acknowledge the role of Shari'ah-compliant securities like Sukuk with denomination of domestic currency in recent years in monetary policy transmission. These Islamic securities helped park surplus liquidity available in interbank Islamic money markets for investment purpose. They recommend that the Central bank 
Hassan, Shah, Alazhar, \& Selim | Towards the Implementation of Monetary Management in Islamic Economic System based on Recent Developments

authorities should work to strengthen the financial intermediation. It would help to make an efficient monetary policy. Similarly, the development of liquid domestic capital markets would also play an important role in transmission mechanism through credit channel of Islamic banks in the GCC countries.

In case of Pakistan, Zaheer, Ongena and Wijnbergen (2013) found that small and less liquid Islamic banks or Islamic banks similar in size and liquidity of conventional banks, reacted like large conventional banks during tight monetary policy and continued supplying credit to economy irrespective of banks'size and liquidity position of banks. Futhermore, they conclude that monetary policy would not be effective in the presence of Islamic banks if they continue growing with double digit as in the case of Pakistan. In other words, the growth of Islamic banking industry would adversely affect the credit view of monetary policy. Hence, monetary authorities should consider the growing sector of Islamic banking in devising the instruments of monetary policy.

Azmat et al. (2020) have promoted the use of state contingent banking, particularly Islamic banking endorsement of it can help neutralize challenges such as debt overhang and lack of optimal risk takings; these are often associated with conventional banking and can eventually manifest into price bubbles and financial crises. The model holds state contingent contracts on the liability and asset side. Holding the contracts as liabilities can reduce liquidity influx from the real economy during heightened macroeconomic risk environments. Furthermore, state contingent banks will not need to excessively lend asset, stabilizing rate volatility. With returns linked to the prices of the underlying assets, state contingent contracts may promote optimal risk-taking.

Selim (2019) shows that if the central bank follows Qard Hasan based monetary policy and lends at zero interest rate, the investment spending (I) will tend to increase to the maximum possible limit, consumption spending (C) will increase because interest sensitive consumption will expand resulting from the $\mathrm{QH}$ based monetary policy, government spending $(G)$ will increase because government will borrow more at zero interest rate, public debt will decrease because of the absence of interest payments, exports $(X)$ will increase because the export industry will reap the benefits of Qard Hasan based monetary policy, cost of production will decrease and comparative advantage for the export industry will improve, there will be massive import substitution because of the low cost of production resulting from the decline in financing cost, and imports $(M)$ may tend to fall - all of which will contribute to the increase in net exports $(X n)$ and trade surplus will increase. Therefore, Qard Hasan based monetary policy will result in simultaneous increase in all the components of aggregate expenditures such as $C, I, G$, and $N x$ which will cause an upward shift in the aggregate expenditure line and equilibrium real 
Hassan, Shah, Alazhar, \& Selim | Towards the Implementation of Monetary Management in Islamic Economic System based on Recent Developments

GDP and employment will increase and unemployment rate will fall. Qard Hasan based monetary policy will tend to expand the real sector of the economy and as a result, potential real GDP or full employment output will continue to increase and and the long run aggregate supply curve will continue to shift to the right. If real output ( $y$ ) increases faster or at least equal to the rate of the increase in additional money supply $(m)$ in Qard Hasan based monetary policy, i.e., if $y>m$, or, if $y=m$, then price level will not increase. Therefore, Qard Hasan based monetary policy has the potential to increase equilibrium real income, employment, comparative advantage, trade surplus and can reduce unemployment rate, inflation rate, public debts, and deficits, and as a result, Qard Hasan based monetary policy will be relatively more effective.

Selim (2015) argues that central bank can buy and sell Sukuk in open market market operations instead of interest-bearing Treasury bills and other interest-based securities. Such efforts will not only eliminate Riba but it will also promote industrialization and productive economic activities which can easily be financed by issuing Sukuk. The expansion of Sukuk will cause an expansion of the real sector of the economy and potential real GDP will increase, employment will increase, and unemployment rate will fall, and the long run aggregate supply curve will shift to the right, and there will be continuous prosperity in the economy. In addition, Islamic Banks can easily participate in buying and selling of the Sukuk in central bank's open market operations and can manage their liquidity position efficiently and, therefore, will not need to keep billions of dollars or Dinars as idle cash for the fear of default risk and do not need to maintain 'excess liquidity' as emphasized by Basu et al. (2015). Thus, Islamic banks can effectively compete the conventional commercial banks and will continue to grow and prosper without limits and constraints.

Selim (2020) proposed Istisna'a-Qard Hasan based monetary policy because Istisna'a or order to manufacture mode of financing is only supported by Hanafi School of Fiqh. Other Schools of Fiqh do not support it because in Istisna'a, both price and product are delayed and delivered later and the Builder or Manufacturer or the Producer must find funds for producing the product(s) and they may need to borrow funds on Riba. To eliminate Riba, Selim (2020) proposed Istisna'a based monetary policy with Qard Hasan where the Builders or the Producers or the Manufacturers will have access to Qard Hasan funds once the Istisna'a contract will be signed. If Istisna'a contract is supported by Qard Hasan, all the Schools of Fiqh may accept the validity of the Istisna'a-Qard Hasan contract, the cost of Istisna'a contract will be lower because more and more Builders or Manufacturers or Producers will be able to participate because of the availability of Qard Hasan, the bidding process will be more competitive and the quality of the final deliverable 
Hassan, Shah, Alazhar, \& Selim | Towards the Implementation of Monetary Management in Islamic Economic System based on Recent Developments

product(s) will be better because the producer will not face shortages of funds and therefore, will be able to afford and use quality inputs and raw materials. Therefore, Istisna'a-Qard Hasan based monetary policy will be most effective and the cost of the manufactured products will be lower, and the quality of the products will be better, and more and more Producers, Manufacturers and Builders will be able to participate in the bidding process which may prevent anchoring bias and escalation commitment in decision making to only a few Suppliers or Builders (Selim, 2020b).

Selim and Hassan (2020) have examined how a central bank (CB) can act as lender of last resort (LOLR) for both Islamic (IB) and conventional interestbased banks by pursuing a Qard Hasan (QH)-based monetary policy (MP). When the $C B$ acts as LOLR by pursuing $Q H$-based MP, it automatically empowers IBs by providing access to borrowing funds from the $\mathrm{CB}$ on $\mathrm{QH}$ basis. The lending capacity of IBs will increase and deposit expansion, loan creation, and aggregate expenditures in the economy will all expand. This will in turn increase real GDP and there will be increase in employment in the economy.

Selim, Hassan, and Rahman (2020) attempt to explore how building a most modern Airport can also be financed by pursuing Istisnas-Sukuk (Order to Manufacture -Sukuk) based expansionary monetary policy (MP). Central Bank (CB) can buy and sell such sukuk (interest-free financing backed by asset ownership and profit) in open market as tools of monetary policy. In this paper, it has been shown that Istisnaa-Sukuk financing will have expansionary monetary policy effects and, as such, it will increase output and consequently reduce unemployment rate. In addition, it will also eliminate public debt and interest payments for the government, and the government will have more funds available for public spending. As a result, economic expansion and prosperity will continue unabated. Eventually, it will help prevent transfer of domestic resources as interest payments to foreign creditors.

Shaikh and Hassan (2019) finds that countries where the banks have higher capital adequacy ratios usually have lower inequality of income. Since remunerative investment accounts in Islamic banking are operated through Mudarabah, the capital buffer would be greater in Islamic banking leading to greater solvency, resilience, and lesser volatility in net banking spreads. Financial inclusion in asset side operations through equity financing ensures that people with more human capital but less financial capital also undertake productive investments, which enhances capital formation and employment creation.

Selim and Hassan (2019) have examined the relative economic performance of two groups of countries where in one group, interest free monetary policy (IFMP) was pursued while in the other group, interest based monetary policy 
Hassan, Shah, Alazhar, \& Selim | Towards the Implementation of Monetary Management in Islamic Economic System based on Recent Developments

(IBMP) was followed. Economic performance is measured by discomfort index (DI)/misery index (MI) - calculated as unemployment rate plus inflation rate. The results revealed that in group y nations, where IFMP was adopted, displayed lower $\mathrm{MI}$ and better economic performance than group $\mathrm{x}$ nations where IBMP was pursued, and the t-test was statistically significant at the 5\% level.

Rashid, Hassan, and Shah (2019) empirically investigate the impact of monetary policy on the credit supply of Islamic versus conventional banks of Malaysia using an unbalanced panel data set over the period 2005-2016. Evidence shows the existence of the credit channel of monetary policy transmission mechanism, with Islamic banks showing more resilience to changes in monetary policy. Furthermore, monetary policy measures affect small-sized banks and less-liquid banks more compared to large-sized and more-liquid banks.

Hassan and Al-Dayel (1988/1989) examine empirically the stability of the demand for money under two different financial systems. One system pays interest on money deposited at the hank and charges interest on hank loans; the other does not pay interest on money deposited in the bank and enters a profit-sharing contract with the bank borrowers instead of charging interest on hank loans. Existing literature backs that interest-free money is more stable than interest-bearing money (Darrat, 1988). This study supports previous findings as the velocity of money and variance are lower for interestfree banking system than for interest-bearing banking system.

Basu, Prasad, and Rodriguez (2015) note that Islamic banks are facing problem of excess liquidity as compared to conventional banking sector in the GCC. This excess liquidity of Islamic banks affects the growth of banks adversely. Likewise, excess liquidity absorbs tight monetary policy actions against the objectives of monetary policy. To meet the excess liquidity problem, they recommend establishing an Islamic money market and modern Shari'ahcompliant instruments for monetary management in Islamic economic framework.

Unlike Sudan and Iran, many Islamic countries like Malaysia, Indonesia, Bahrain, Bangladesh, Pakistan, Turkey, and Saudi Arabia operate a dualbanking system. Therefore, the bank credit supply in these countries can be viewed in two perspectives. They are (i) the existing traditional lending channel of monetary policy and (ii) Islamc banking credit channel. More recently, Zulkhibri and Sukmana (2017) in Indonesia, Shah and Rashid (2019), Rafay and Farid (2019), Zaheer, Ongena, and Wijnbergen (2013) in Pakistan, and Akhatova, Zainal and Ibrahim (2016), Stepanchuk and Tsyrennikov (2015) in Malaysia, verified the credit channel through Islamic banks in the transmission mechanism of monetary policy. Overall, these empirical studies 
Hassan, Shah, Alazhar, \& Selim | Towards the Implementation of Monetary Management in Islamic Economic System based on Recent Developments

have found very interesting results about modern practices of monetary management in Islamic economic context. AAOIFI (2010) and IFSB (2017) are providing standards and regulatory guidelines to bring Islamic modes of financing in line with modern contemporary practices.

\section{Conclusion}

In Islamic economics and finance, monetary management is integral to policymaking. Along with the prohibition of Riba in the Quran, the Prophet Muhammad (PBUH) closed the backdoor of interest through managing exchange of prevailing Roman Dinar and Persian Diram and other six commodities based on same quantity at spot transaction. In the first Islamic state, credit was managed through Islamic modes of finance: Murabaha for traders, Musharkah for pooled investment, Salam for agricultural sector, Istisnaa for manufacturing production units, and ljarah for short-term usufruct of object. All these financing instruments played an important role in monetary management as alternate souces of fund. Then, Abdul Malik introduced $1^{\text {st }}$ Islamic Dinar in 696 A. D and it became a major international currency throughout the five centuries of medieval history. Similarly, we find that several econmists have tried to frame the concept of Islamic monetary management in modern framework quite successfully.

This study strongly recommends the adoption of interest free Islamic monetary policy across the countries. The current study has attempted to create an urge and humble awareness that Islamic monetary policy is not only an alternative to conventional interest based monetary policy, but it is superior in many respects and relatively more effective in bringing full employment output, income and prosperity and can minimize or even eliminate the threats of financial crisis. The policy makers, practioners, regulators and central bankers around the globe must come forward and pursue interest free Islamic monetary policy and maximize investment spending, minimize the cost of borrowing and thus the economy will be operating at full employment and eventually poverty, hunger, bankruptcy, mass unemployment and financial crisis will be the sad events of the past.

In the modern era, Islamic banking is an emerging discipline in compliance with Islamic law. Islamic financial products in Islamic economic framework are designed which lead to the development of real economy. Indeed, as compared to conventional banks, Islamic banks are found with different composition of balance sheet and distinguished contractual obligations. Therefore, we have reviewed the theoretical and empirical literature on Islamic monetary management to know current position of literature. In more recent studies, we discussed the empirical literature on instruments and 
Hassan, Shah, Alazhar, \& Selim | Towards the Implementation of Monetary Management in Islamic Economic System based on Recent Developments

transmission mechanism of monetary policy in dual banking economies. In implementing monetary policy through Islamic banks, a central bank can only use instruments in accordance with Islamic financial theory. Conceptually, Islam provides a degree of freedom to Scholars to update Islamic knowledge stream through litehad with necessary conditions. After reviewing the literature, we find that most of the traditional monetary instruments that do not rely on interest are consistent with Islamic principles and require only a minor amendment.

The Islamic banking and financial industry has achieved a rapid growth in different markets, and it has expanded into new geographies. Therefore, policymakers of concerning countries should observe the notion of conducting monetary policy by Islamic finance ideals to achieve macroeconomic goals. Further, we recommend to practitioners to consider all four major views on Islamic Monetary policy and choose the one which will create maximum possible positive effects in the form of achieving full employment, potential real GDP, low unemployment and low inflation rates, maximum possible economic growth rates, prosperity, and is closer to the principles of Qur'an and Sunn'ah. For academicians, this paper opens new horizons of research on monetary management in Islamic economic framework for making Islamic banking industry closer to the objectives of Shari'ah. 
Hassan, Shah, Alazhar, \& Selim | Towards the Implementation of Monetary Management in Islamic Economic System based on Recent Developments

\section{References}

AAOIFI, (2010). Accounting and auditing standards for Islamic financial institution. Bahrain: AAOIFI.

Abdul-Rahman, Y. (2011). The Art of Islamic banking and finance: Tools and techniques for community-based banking. New Jersey: John Wiley \& Sons, Inc., Hoboken.

Adebayo, R. I., \& Hassan, M. K. (2013). Ethical principles of Islamic financial institutions. Journal of Economic Cooperation and Development, 34(1), 63-90.

Ahmad, K. (1984). Preface. In U. Chapra, Towards a just monetary system, Leicester: The Islamic Foundation, UK, 5-12.

Akhatova, M., Zainal, M. P., \& Ibrahim, M. H. (2016). Banking models and monetary transmission mechanisms in Malaysia: Are Islamic banks different? Economic Papers, 35(2), 169-183.

Aktheruddin, M. (2016). Reemergence of Islamic Monetary Economics: A Review of Theory and Practice. Munich Personal RePEc Archive (MPRA), Inceif, Malaysia, Paper No. 7208, 1-29.

Alaro, A. R., \& Hakeem, M. (2011). Financial engineering and financial stability: The role of Islamic financial system. Journal of Islamic Economics, Banking and Finance, 7 (1), 34-55.

Al-Jarhi, M. (1983). A Monetary and Financial Structure for an Interest-Free Economy: Institutions, Mechanism and Policy. Money and Banking in Islam, Institute of Policy Studies, Islamabad, 69-87.

Arena, M., Reinhart, C. M., \& Vázquez, F. (2006). The lending channel in Emerging economics: Are foreign banks different?

Ariff, M. (1988). Islamic banking. Asian-Pacific Economic Literature, 2(2), 4864.

As-Sadr, K. (1989). Money and Monetary Policies in Early Islamic Period. In A.H. Bakir, \& A. Mirakhor, Easy on latishad: The Islamic Approach to Economic Problems, Maryland: Silver Spring, 199-217.

Azmat, S., Hassan, M. K., Ghaffar, H., \& Azad, A. S. (2020). State contingent banking and asset price bubbles: The case of Islamic banking industry. Global Finance Journal, 100531.

Basu, R., Prasad, A., \& Rodriguez, S. L. (2015). Monetary Operations and Islamic Banking in the GCC; Challenges and Options. International Monetary Fund (IMF), Paper No. 15/234, 1-38.

Bernanke, B., \& Blinder, A. (1995). Inside the Black Box: The Credit Channel of Monetary Policy Transmission. Journal of Economic Perspectives, 9(4), 27-48. 
Hassan, Shah, Alazhar, \& Selim | Towards the Implementation of Monetary Management in Islamic Economic System based on Recent Developments

Cevik, M. S., \& Teksoz, M. K. (2012). Lost in transmission? The effectiveness of monetary policy transmission channels in the GCC countries. International Monetary Fund.

Chapra, M. U. (1985). Towards a just monetary system (Vol. 8). International Institute of Islamic Thought (IIIT).

Chapra, M. U. (1996). Monetary Management in an Islamic Economy, Islamic Economic Studies, 4(1), Available at SSRN: https://ssrn.com/abstract=3165360

Chapra, M. U. (2008). The Islamic Vision of Development in the Light of the Maqsid al-Shari'ah. . Jeddah: Islamic Research and Training Institute (IRTI), Islamic Development Bank.

Charap, M. J., \& Cevik, M. S. (2011). The behavior of conventional and Islamic bank deposit returns in Malaysia and Turkey. International Monetary Fund.

Choudhry, N., \& Mirakhor, A. (1997). Indirect instruments of monetary control in an Islamic Financial system. Islamic Economic Studies, 4(2), 27-65.

Ernst and Young. (2016). World Islamic banking competitiveness report 2016. https://ceif.iba.edu.pk/pdf/EY-

WorldlslamicBankingCompetitivenessReport2016.pdf

Farahani, Y. G., \& Dastan, M. (2013). Analysis of Islamic banks' financing and economic growth: a panel cointegration approach. International Journal of Islamic and Middle Eastern Finance and Management, 6(2), 156-172.

Hardianto, E. (2004). Shariah Transmission Mechanism in Indonesia. Journal of Economic Cooperation and Development 8(2), 20-38.

Hassan, M. K., \& Aldayel, A. Q. (1998). Stability of money demand under interest-free versus interest-based banking system. Humanomics.15(1), 167-186.

Ibrahim, M. H. (2017). The bank lending channel of monetary policy transmission in a dual banking system. Journal of Islamic Monetary Economics and Finance, 2(2), 193-220.

IFSB. (2019). Islamic Financial Services Industry Stability Report. Kuala Lumpur: IFSB.

IIIE. (1999). IIIE's Blueprint of Islamic Financial System. IsImaabad: International Institute of Islamic Economics.

Iqbal, Z. (1997). Islamic financial systems. Finance \& Development 43, 42-45.

Ireland, P. N. (2005). The Monetary Transmission Mechanism. Federal Reserve Bank of Bostan. No. 06-1 
Hassan, Shah, Alazhar, \& Selim | Towards the Implementation of Monetary Management in Islamic Economic System based on Recent Developments

Islahi, A. A. (2008). Thirty Years of Research in the History of Islamic Economic Thought: Assessment and Future Directions. Islamic Economics Research Centre, King Abdulaziz University, Jeddah. K.S.A, 1-16.

Kaleem, A., \& Isa, M. (2006). Islamic Banking and Money Demand Function in Malaysia: An Econometric Analysis. Pakistan Economic and Social Review, XLIV (2), 277-290.

Khan, M. S. (1986). Islamic Interest-Free Banking. IMF Staff Papers 33, 1-27.

Khan, M. S., \& Mirakhor, A. (1990). Islamic banking: Experiences in the Islamic Republic of Iran and in Pakistan. Economic development and cultural change, 38(2), 353-375.

Kia, A., \& Darrat, A. F. (2007). Modeling money demand under the profitsharing banking scheme: Some evidence on policy invariance and longrun stability. Global Finance Journal, 18(1), 104-123.

Kuran, T. (1986). The economic system in contemporary Islamic thought: Interpretation and assessment. International Journal of Middle East Studies, 18(2), 135-164.

Majid, M. S., \& Hasin, Z. (2012). Islamic Banks and Monetary Transmission Mechanism in Malaysia. Journal of Economic Cooperation and Development, 35(2), 137-166.

Mansoori, M. T. (2010). Fiqh Regulations on Finance and Business Transaction. Ulil Alba Institute, PascaSarjana, Universitas Ibn Khaldun, Bogor, Indonesia, 1-26.

Mishkin, F. S., \& Schmidt-Hebbel, K. (2007). Does inflation targeting make a difference? NBER Working Paper No. w12876, 1-66.

Naqvi, S. N. H. (1981). Ethics and economics: An Islamic synthesis. Islamic foundation.

Obstfeld, M., \& Rogoff, K. (1996). Exchange Rate Dynamics Redux. Journal of Political Economy 103(3), 624-660.

Rafay, A., \& Farid, S. (2019). Islamic banking system: a credit channel of monetary policy: evidence from an emerging economy. Economic Research-Ekonomska Istraživanja, 32(1), 742-754.

Rashid, A., Hassan, M. K., \& Shah, M. A. R. (2020). On the role of Islamic and conventional banks in the monetary policy transmission in Malaysia: Do size and liquidity matter? Research in International Business and Finance, 52, 101123.

Sanrego, Y. D., \& Rusydiana, A. S. (2013). Transmission Mechanism in Dual Monetary System: Comparison between Shariah and Conventional Monetary System. Journal of Islamic Economics, Banking and Finance, 9(2), 27-44. 
Hassan, Shah, Alazhar, \& Selim | Towards the Implementation of Monetary Management in Islamic Economic System based on Recent Developments

Selim, M. (2015). Effectiveness of Sukuk as a Tool of Monetary Policy Journal of Islamic Economics, Banking and Finance, 2 (3), 47-60.

Selim, M. (2019). The effectiveness of Qard-al-Hasan (interest free loan) as a tool of monetary policy. International Journal of Islamic and Middle Eastern Finance and Management, 12(1), 130-151.

Selim, M. (2020), Istisna'a based monetary policy and its effectiveness in achieving full

employment and price stability, International Journal of Islamic and Middle Eastern Finance and Management, 13(4), 707-726.

Selim, M., Hassan, M. K., \& Rahman, M. (2019). Financing superinfrastructures using Istisna'a-Sukuk based monetary POLICY for faster economic development. Journal of Economic Cooperation \& Development, 40(4), 139-161.

Selim, M. (2020a). Financing homes by employing ljara based diminishing Musharaka. International Journal of Islamic and Middle Eastern Finance and Management.13(5), 787-802.

Selim, M. (2021). The effects of eliminating Riba in foreign currency transactions by introducing global FinTech network. International Journal of Islamic and Middle Eastern Finance and Management, 14(3), 506-523.

Selim, M. (2020b). Escalation commitment in decision making and its possible effects in the long run In 2020. International Conference on Decision Aid Sciences and Application (DASA) (pp. 686-691). IEEE.

Selim, M., \& Farooq, M. O. (2020). Elimination of poverty by Islamic value based cooperative model. Journal of Islamic Accounting and Business Research, 11(5), 1121-1143.

Selim, M., \& Hassan, M.K (2020). Qard Hasan-based monetary policy and the role of the central bank as the lender of last resort. Journal of Islamic Accounting and Business Research, 11(2), 326-345.

Selim, M., \& Hassan, M.K. (2019). Interest free monetary policy and its impact on inflation and unemployment rates. ISRA International Journal of Islamic Finance, 11(1), 46-61.

Selim, M. (2015a). Takaful Based on Business: Partnership with Special Reference to Bahrain. International Journal of Excellence in Islamic Banking and Finance, 182(3080), 1-8.

Selim, M. (2013). Eliminating interest costs in financing trade deficits by pursuing and maintaining fully convertible domestic currency. Journal of Islamic Economics, Banking and Finance, 113(913), 1-20. 
Hassan, Shah, Alazhar, \& Selim | Towards the Implementation of Monetary Management in Islamic Economic System based on Recent Developments

Shah, M. A., Rashid, A., \& Khaleequzzaman, M. (2017). Capital Structure Decisions in Islamic Banking: Empirical Evidence from Pakistan. Journal of Islamic Banking and Finance, 34(2), 88-103.

Shah, S. M., \& Rashid, A. (2019). The credit supply channel of monetary policy transmission mechanism: an empirical Investigation of islamic banks in Pakistan Versus Malaysia. Journal of Islamic Monetary Economics and Finance, 5(1), 21-36.

Shaikh, S. A., \& Hassan, M. K. (2020). Economic analysis of Islamic monetary framework and instruments. In Islamic Monetary Economics (pp. 6076). Routledge.

Siddiqi, M. N. (2006). Islamic banking and finance in theory and practice: A survey of state of the art. Islamic economic studies, 13(2), 1-48.

Stepanchuk, S., \& Tsyrennikov, V. (2015). Portfolio and welfare consequences of debt market dominance. Journal of Monetary Economics, 74 (2), 89101.

Sukmana, R., \& Kassim, S. H. (2010). Roles of the Islamic Banks in the Monetary Transmission in Malaysia. International Journal of Islamic and Middle Eastern Finance and Management, 3I (1), 7-19.

Tahir, S. (2013). Fiscal and Monetary Policies in Islamic Economics: Contours of an Institutional Framework. Islamic Economic Studies, 21(2), 1-22.

Taylor, J. B. (1995). The Monetary Transmission Mechanism: An Empirical Framework. Journal of Economic Perspectives, 9(4), 11-26.

Uzair, M. (1982). Central banking operations in an interest-free banking system. Monetary and Fiscal Economics of Islam. Jeddah: International Centre for Research in Islamic Economics, 211-236.

Zaheer, S., Ongena, S., Wijnbergen, \& G., S. J. (2013). The Transmission of Monetary Policy Through Conventional and Islamic Banks. International Journal of Central Banking Doha, (8)2, 175-224.

Zarqa, M. (1983). Stability in an interest-free Islamic economy: A Note. Pakistan Journal of Applied Economics, 11(2), 181-188.

Zulkhibri, M., Ismail, A. G., \& Hidayat, S. E. (Eds.). (2016). Macroprudential regulation and policy for the Islamic financial industry: Theory and applications. Springer.

Zulkhibri, M. (2018). The impact of monetary policy on Islamic bank financing: bank-level evidence from Malaysia. Journal of Economics, Finance and Administrative Science, 23(46), 306-322.

Zulkhibri, M., \& Sukmana, R. (2017). Financing channels and monetary policy in a dual banking system: Evidence from Islamic banks in Indonesia. Economic Notes: Review of Banking, Finance and Monetary 
Hassan, Shah, Alazhar, \& Selim | Towards the Implementation of Monetary Management in Islamic Economic System based on Recent Developments

Economics, 46(1), 117-143.

Zulkhibri, M., Manap, T. A. A., \& Muneeza, A. (2019). Islamic Monetary Economics and Institutions. Springer.

\section{Arabic References}

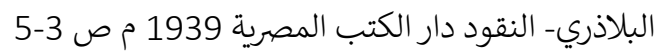

د/ عادل زيتون - عندما كان الدينار الإسلامي عملة عالمية مجلة 》العربيه العدد 508 مارس ص46 2001

عبد الله كنون- الدرهم والدينار عملتان عايشتا العرب بضعة عشر قرناً مجلة 》العربيه العدد 1874

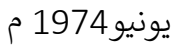

